\title{
Ranchland Ownership Dynamics in the Rocky Mountain West
}

\author{
Hannah Gosnell ${ }^{1}$ and William R. Travis ${ }^{2}$ \\ Authors are ${ }^{1}$ Research Associate, Center of the American West, University of Colorado, Boulder, CO 80309-0282; and \\ ${ }^{2}$ Associate Professor, Department of Geography, University of Colorado, Boulder, CO 80309-0260.
}

\begin{abstract}
We examine the rate of ranch sales and the nature of ranchland ownership change in the Rocky Mountain region. Interest in this phenomenon is high because ranches represent the largest parcels of private open space and relatively natural landscapes in the West and because anecdote, media coverage, and testimony from range professionals suggest that a significant turnover in ranch ownership is underway. Ranch sales activity is of special interest to groups seeking to conserve both ranchlands as habitat and ranching as part of the regional economy and culture. Very little work has been conducted on ranchland ownership per se, although we were able to build on studies of ranchland prices and on surveys that included some questions relating to operational goals, tenure, and future plans. The literature also offers a foundation for a ranch ownership typology. We tracked sales of ranch properties of 400 or more acres in 3 Rocky Mountain counties for the period 1990-2001, finding turnover (sale) rates from $14 \%$ to $45 \%$. With help from local real estate agents, appraisers, and county officials, we classified ranch buyers according to a simple typology and found that the majority of acres sold $(54 \%)$ went to "amenity buyers," and $62 \%$ of acres sold went to out-of-state buyers. This 12-year slice of ranch sales suggests a significant ranchland ownership transition to a new type of owner is, indeed, underway in the Rockies.
\end{abstract}

\section{Resumen}

Examinamos la tasa de venta de ranchos y la naturaleza de cambio de la propiedad de los ranchos en la región de las Montañas Rocallosas. El interés de este fenómeno es alto porque los ranchos representan el más grande terreno de espacio abierto privado y paisajes relativamente naturales del Oeste y porque por anécdotas y testimonios de profesionales de manejo de pastizales sugieren que un cambio significativo de la propiedad de los ranchos esta ocurriendo. La actividad de venta de ranchos es de especial interés para grupos que buscan conservar los ranchos como hábitat y con sus actividades propias del rancho como parte de la economía y cultura regional. Muy poco trabajo se ha realizado sobre la propiedad de los ranchos per se, aunque fuimos capaces de diseñar estudios sobre los precios de los ranchos y reconocimientos que incluyen algunas cuestiones relacionando las metas operacionales, los derechos de posesión del terreno y los planes futuros. La literatura también ofrece un fundamento para tipificar la propiedad de los ranchos. Rastreamos las ventas de los ranchos de 400 o más acres en tres condados de las Montañas Rocallosas efectuadas durante el periodo de 1990-2001, encontrando tasas de retorno (ventas) del 14\% al $45 \%$. Con la ayuda de agentes locales de bienes y raíces, valuadores y oficiales del condado clasificamos a los compradores de los ranchos de acuerdo a una tipificación simple y encontramos que la mayoría de los acres vendidos $(54 \%)$ fueron a parar a "compradores recreacionales," y $62 \%$ de los acres se vendieron a compradores de fuera del estado. Este periodo de 12 años de ventas de ranchos sugiere que efectivamente en la Montañas Rocallosas se esta dando una transición significativa en la propiedad de los ranchos hacia un nuevo tipo de propietario.

Key Words: ranch sales, landowner typology, amenity buyer, ownership transition

\section{INTRODUCTION}

Anecdote, media coverage, testimony from range professionals, and limited research indicate that a significant turnover in the ownership of private ranchland is underway in the American West. The nature of ranch ownership has changed episodically over time, such as when smaller ranches and farms were absorbed into larger units during the depression and drought of the 1930s. Previous episodes of significant

This research was funded by The William and Flora Hewlett Foundation and The Nature Conservancy.

Correspondence: Hannah Gosnell, Center of the American West, University of Colorado, 282 UCB, Boulder, C0 80309-0282. Email: gosnell@colorado.edu

Manuscript received 4 December 2003; manuscript accepted 6 November 2004. ownership change, however, kept ranchland in the hands of what can be thought of as traditional ranchers: owneroperators or some form of family corporation or partnership focused mainly on livestock production (i.e., agricultural owners sold to other agriculturalists). The current ranch ownership change, many observers argue, is marked by a transition from traditional ranchers to a new type of owner not as dependent or focused on livestock production, owners likely to operate in a significantly different fashion and to treat the land differently.

Ownership is an important human dimension of rangeland health and sustainability (Mitchell 2000), but our understanding of the current dynamics of ranch real estate is poor, limited by the difficulty of collecting and analyzing data on private land ownership. Several research questions present themselves and speak to the future of ranching in the American West: What is 
the rate and pattern of ranch ownership turnover? What does this imply for the ranching economy and culture and for rangeland management? What are the goals of new owners? We begin to address such questions in this article with an analysis of the rate and pattern of ranch sales in selected areas and with an attempt to assess the disposition of new owners.

As ranches change ownership, the land resource might be split up (subdivided), remain roughly the same, or even be agglomerated with other parcels to create a larger ranch. We focus on ranches that remain intact or enlarge as they change hands, thus representing intact production units and habitats. Obviously, though, the potential for subdivision as ranches change hands is an important issue deserving attention in future research.

\section{Literature Review and Conceptual Framework}

Anecdote and indirect evidence indicate that western ranches are changing hands at an unusually high rate and in a fashion that will result in significant changes in ranch configuration, management, and the role ranches play in the social and ecological health of western rangelands (Holechek 2001). Several studies cite the increasing average age of ranch owner-operators as prima facie evidence that ranch transfers are increasing or are likely to be more frequent in the near future as ranchers retire (e.g., Peterson and Coppock 2001); and ranchers increasingly view selling to developers as a viable or even inevitable alternative to intergenerational inheritance for a variety of reasons (Liffmann et al. 2000).

Ranch ownership is one of several human dimensions of rangelands. Although extensive research illustrates how land management affects land quality, we know much less about ranchland ownership per se. Ranch ownership goals are complex. Agricultural economists have known for decades that western ranches are not especially efficient producers of livestock and do not offer competitive profit or return on investment. Smith and Martin (1972) showed 3 decades ago that Arizona ranches perform poorly economically; many yield negative returns while simultaneously selling for high prices in the real estate market. Subsequent work has revealed this pattern in many parts of the West (see, for example, Fowler and Gray 1988; Bartlett et al. 1989). Economists conclude from these analyses that ranchers obtain a wide range of nonmonetary benefits from ranch ownership, including lifestyle, land and resource stewardship, and a desirable role in the local community (Rowan 1994).

It is widely argued that ranches across much of the West are sold-or at least are marketed-at prices far above their agricultural value (Holechek 2001; Torell et al. 2004), and that this reveals a large demand for ranches by nonranchers who are most interested in the amenities of owning a ranch. Indeed, Smith and Martin (1972) used the price disparity as the basis for calculating what could be called the "amenity increment" in ranch land prices in Arizona; but they assumed that the consumer of that amenity increment was a traditional rancher, that is, an owner-operator mainly focused on livestock production but also enjoying the lifestyle amenity.

Analysts recently have begun to assume that ranch sales at amenity prices reflect a switch away from livestock production to a focus on consuming land amenities as the dominant goal. The effect began to show up in ranchland studies, especially in the 1990s. In their study of New Mexico ranch prices, Torell and Kincaid (1996) excluded some ranch sales in areas that they believed were affected by recreational or development potential in an attempt to obtain more purely agricultural production values. In a more recent study, Torell et al. (2003) concluded that "capitalization of annual earnings explained little of the market value for most New Mexico ranches," whereas the presence of wildlife had a significant influence on ranch values (p. 4). Sengupta and Osgood (2003) found that access to roads, cities, and neighbors, as well as overall attractiveness, raised ranchland sale prices in Arizona. Rowan and Workman (1992) included such nonagricultural influences in their study of Utah ranch sales, but found them insignificant.

The perceived transition in ranchland ownership out of the hands of "traditional" ranch families has led several researchers to develop new typologies of western ranchers and ranches. Ranch typologies are traditionally based on production types (e.g., cow-calf, shed lambing, sheep and cattle, buffalo, etc.; see, for example, Anderson et al. 1993). A few researchers began to recognize nonproduction ranch types in the late-1980s (Bartlett et al. 1989). Coppock and Birkenfeld (1999) used socioeconomic data and cluster analysis to identify 5 types of owners, including "hobbyists," those who obtained $>50 \%$ of their income from nonlivestock sources. In a survey of Utah producers, Peterson and Coppock (2001) asked respondents to type themselves as "profit oriented" or "hobby oriented" and found that the latter group, defined as those for whom "livestock were raised more for lifestyle reasons and ancillary income generation compared with a profit-minded business orientation" (p. 109), controlled about $20 \%$ of private grazing land. Gentner and Tanaka (2002) split western public land ranchers into 2 main types, hobbyists and professionals, each with 4 subcategories, based on why the owners were in ranching and how they might respond to public land policy changes. Their "hobbyist" category runs from part-time ranchers actually trying to make a profit from livestock production to "trophy ranchers" who rank the need for profit as low when compared with the amenity benefits of ranch ownership. This was the first recognition of the "trophy ranch" in the research literature. Their mail survey of 1052 public lands ranchers found an almost even split between professionals and hobbyists. Sengupta and Osgood (2003) observe that more than $60 \%$ of the agricultural operations in the 1997 US census of agriculture could be classified as "hobby" farms and ranches if defined as operations with $<\$ 10000$ in sales. The United States Department of Agriculture (USDA) Economic Research Service recently developed a new typology for categorizing farms and ranches into "more homogeneous groups than classifications based on sales volume alone," based largely on the occupation of operators (USDA 2000). The typology includes a "residential/lifestyle" class.

Substantial prima facie evidence suggests that recent ranch buyers are more likely to be lifestyle seekers than professional ranchers. Indeed, an informal survey of ranch real estate catalogs, like the glossy Rocky Mountain Farm and Ranch Magazine, suggests that the primary market for large operations is what Gentner and Tanaka (2002) would call trophy ranchers. Still, depending on how one interprets Gentner and Tanaka's categories (2002), such as retired hobbyists, sheep ranchers, and both classes of family ranchers, it can be concluded from their results that slightly over half of the West's 
public lands ranches are still in something akin to traditional ownership and use. The region's ranchlands are only partway through a major transition.

If many, perhaps most, new owners in the Rocky Mountain West seek goals in addition to, or even in place of, livestock production, then ranch ownership change is likely to result in land use and ecological changes. Not every ranch sale results in a significant change in ranch management, of course, but a growing amenity market for ranchland has the potential to affect many land qualities of interest to range managers and land conservationists (Huntsinger et al. 1997). Ranches are not only economic production units that contribute to local and regional economies but are often important parcels of private open space that provide valuable habitat, scenery, and other ecological and social services. Although individual ranchers hold differing views on their role in maintaining habitat and preserving biodiversity, there is no doubt that private open spaces are of critical importance to the future ecological health of the Rocky Mountains, even though more than half of the surface area of the region is federally owned (Baron 2002).

Holechek (2001) suggests that current western ranch ownership and operation patterns are changing because of the deployment of significant new wealth into ranchlands, especially during the past decade. Holechek believes this change is likely to continue, and perhaps intensify. Thus, it makes sense to attempt to quantify the changing nature of ranchland ownership. We could find no studies in the range and ranching literature that examined contemporary ownership change in detail, although it has been a minor dimension of some surveybased studies (Liffmann et al. 2000) and has been an element of historical studies of ranching (Jordan 1993; Starrs 1998). After beginning this study, we realized that one reason so little work has been done on this obviously important issue is that the data are hard to acquire and awkward to work with. Historical land ownership information in the United States resides mostly in the arcane deed-and-plat system of paper records held only in each county's courthouse. Current ownership data are public but often difficult to access. Fortunately, some county land records are becoming digitized and are available online. Thus, it is slowly becoming possible to take a more systematic look at ranchland ownership dynamics, and we consider this study a first, detailed step toward filling the knowledge gap about the rate and nature of ownership change.

\section{METHODS}

We are unaware of previous research that examines ranch property ownership directly through property records, so we explain our methods in some detail to encourage both critical feedback and replication by other researchers. We analyzed ranch ownership change by gathering land ownership data and sales data from county tax assessors, private appraisers specializing in agricultural properties, realtors, and others familiar with agricultural sales in the study counties. Although land ownership data are public, we follow standard social science protocol and report data only in the aggregate so that we do not reveal personal information about sellers and buyers.
In this study, "ranchland" refers to the deeded land of a ranch unit. This land may not be contiguous. A "ranch" is typically composed of one or more deeded parcels, perhaps with outlying plots, used in a systematic and integrated fashion, often in conjunction with leased private land and public grazing allotments. Total deeded acreage varies among western and Rocky Mountain ranches, from small operations of a few hundred acres to typical large ranches that comprise 1000 or more deeded acres (Gentner and Tanaka 2002).

Our focus is on the fate of larger ranches that remained intact after a sale (that were not subdivided for residential or other uses) and that could be functional agricultural production units, if so desired by their owners. Based on recommendations from agricultural extension agents, realtors, appraisers, and others familiar with the agricultural communities studied, we set the threshold at 400 deeded acres. This kept us out of the "ranchette" market but included smaller ranches that could still be considered viable economic units if supplemented with offranch income or leased land.

For each county analyzed, we spent several days in the field getting acquainted with the local ranching geography and conducting interviews with the agricultural community, realtors, appraisers, conservationists, and representatives of local and federal government. We collected land ownership data from both local and state agencies. In Wyoming and Colorado, we obtained general land ownership data (e.g., the amount and geographic location of public and private land) from each county's geographic information system (GIS) specialist. In Montana, general land ownership data were available from the Montana Natural Resource Information System (NRIS). ${ }^{1}$ We collected detailed data on private land ownership from the Departments of Revenue (DOR) in Montana and Wyoming and from the Routt County assessor in Colorado. In all 3 states, we requested ownership data for all parcels designated as "agricultural" for tax purposes in 2002 (the most recent data available). We collected land parcel data from each county, working to reconcile different software, data systems, and ownership identification techniques, to create GIS parcel layers (maps). We standardized and combined the ownership data to identify all land owned by owners with 400 acres or more, and we linked the sales data to these layers to reveal the spatial pattern of sales and ownership in each county. ${ }^{2}$

We worked with appraisers familiar with each case study county to characterize changes in ranch ownership. We found that rural appraisers generally maintained the most comprehensive sales databases (as opposed to county assessors, realtors, or lending agencies) but varied in their willingness to share their data, which may be considered proprietary. In reporting results, we do not reveal owner names or other sale identifiers (e.g., parcel identification number or price), although we do briefly describe some specific sales and related land use changes as examples without identifying the individuals or properties involved. We were able to obtain sales data from at least 2 ranch real estate professionals in each county. We calculated the number of sales of 400 deeded acres or more

\footnotetext{
${ }^{1}$ http://nris.state.mt.us

${ }^{2}$ These and other ownership maps and reports can be viewed on our website: www.centerwest.org/ranchlands.
} 
Table 1. Working typology for ranch buyers.

\begin{tabular}{|c|c|}
\hline Type & Definition \\
\hline Traditional Rancher & $\begin{array}{l}\text { Generally, a full-time owner-operator raising livestock } \\
\text { for profit without the aid of a ranch manager; } \\
\text { may engage in some off-ranch work (or on-ranch } \\
\text { work unrelated to livestock, such as outfitting) } \\
\text { but derives the majority (or at least in many } \\
\text { years, a significant portion) of his or her income } \\
\text { from the ranch }\end{array}$ \\
\hline Part-time Rancher & $\begin{array}{l}\text { Does his or her own ranching but often has a full-time } \\
\text { job off the ranch; ranch income is generally less than } \\
\text { the off-ranch income; usually smaller operations }\end{array}$ \\
\hline Amenity Buyer & $\begin{array}{l}\text { Purchases a ranch for ambience, recreation, and other } \\
\text { amenities, not primarily for agricultural production; } \\
\text { often an absentee owner; may have some interest } \\
\text { in ranching but, generally, hires a ranch manager } \\
\text { who makes most day-to-day decisions and does } \\
\text { the majority of the work; or he or she might lease } \\
\text { the majority of the land and cattle to another } \\
\text { rancher; majority of amenity buyers' personal income } \\
\text { is, by definition, from off-ranch sources; economic } \\
\text { viability of the ranch is usually not an issue }\end{array}$ \\
\hline Investor & $\begin{array}{l}\text { Buys primarily for investment, often with the intent to } \\
\text { resell in the short term }\end{array}$ \\
\hline Corporation & $\begin{array}{l}\text { Typically purchases ranch to function as } 1 \text { unit in a } \\
\text { large network of related operations and holdings } \\
\text { elsewhere; ranch is operated by a manager }\end{array}$ \\
\hline Developer & $\begin{array}{l}\text { Buys the land with intention to subdivide and sell to } \\
\text { others, with profits from that sale the main objective }\end{array}$ \\
\hline $\begin{array}{l}\text { Conservation } \\
\text { Organization }\end{array}$ & $\begin{array}{l}\text { Buys ranch with intent to manage for habitat, wildlife, } \\
\text { and other ecological values }\end{array}$ \\
\hline Other & $\begin{array}{l}\text { Includes state and federal land management agencies, } \\
\text { churches, independent loggers, grazing co-ops, } \\
\text { and dude ranches }\end{array}$ \\
\hline
\end{tabular}

(a "ranch") between 1990 and 2001 and the total acres sold, median sale size, median price per acre, and acres sold to outof-state buyers.

Because ranch sales are generally notable local events, and given the comprehensive nature of county and appraiser databases, we feel confident that few, if any, sales have been omitted. However, because data availability and costs limited us to an analysis of the 1990s and early 2000s, we cannot determine how typical this period is historically except to cite arguments by ranch and range professionals that the West is experiencing a marked transition in ranch ownership.

Finally, to assess the changing nature of ranch ownership, we categorized all buyers based on their characteristics at the time of purchase. We did this by asking a panel of individuals familiar with the agricultural communities in each of our case study counties (ranchers, realtors, appraisers, assessors, agricultural extension agents, and federal grazing specialists) to classify the goals of each purchaser using a typology slightly modified from Gentner and Tanaka (2002) (Table 1).

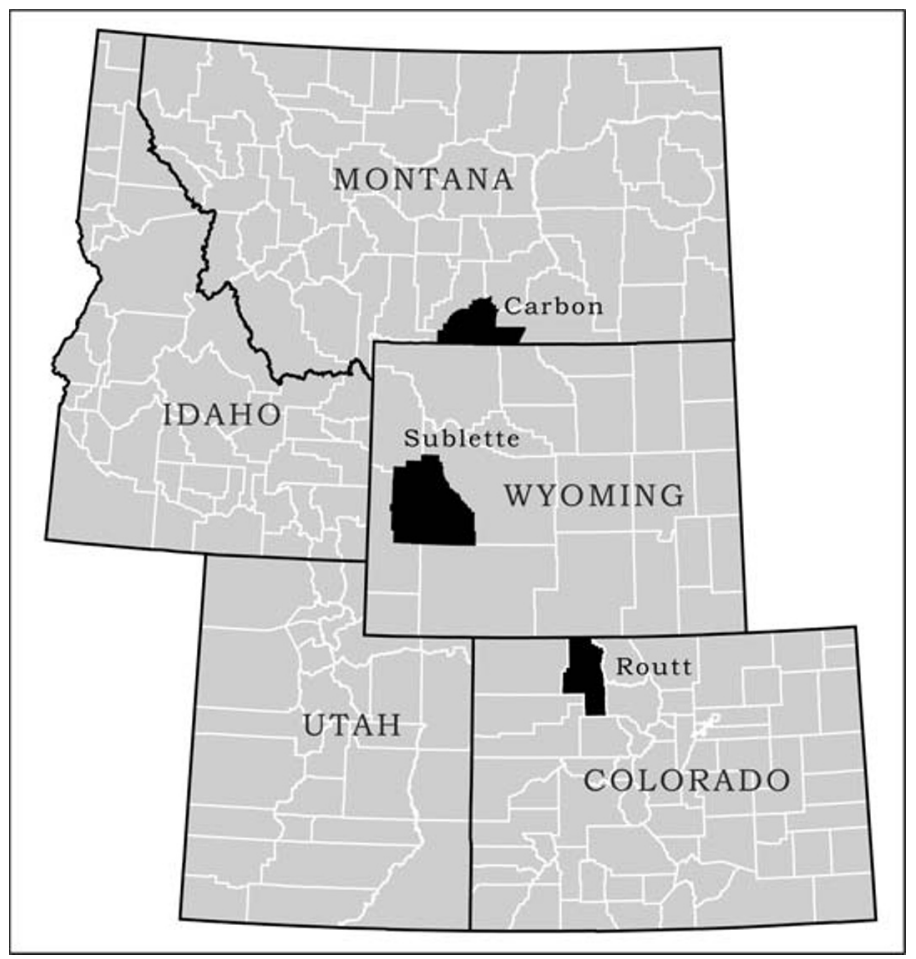

Figure 1. The 3 case study counties.

We chose study counties according to criteria that linked data availability to an independent measure of prime ranchland and the threat of ranchland development (American Farmland Trust [AFT] 2002). ${ }^{3}$ We selected 3 counties for detailed analysis: Routt County, Colorado; Sublette County, Wyoming; and Carbon County, Montana (Fig. 1). These ranged across the threat scale of the AFT and offered reasonable data acquisition opportunities. The counties represent, we believe, typical conditions in the Rocky Mountains: all 3 counties maintain some traditional ranching; one encompasses a major destination resort (Routt); one is much less developed but still experiencing significant interest in ranch real estate (Sublette); and one remains relatively rural (Carbon).

\section{RESULTS}

Our 3 study counties encompass nearly 2 million acres of private agricultural land (Table 2). Most of this is ranchland as opposed to row crop farms, and about 475000 acres (nearly a quarter of it) changed hands during the study period.

\section{Routt County, Colorado}

Located in the northwest corner of Colorado on the Wyoming border, Routt County maintains a limited cattle-ranching industry alongside a highly developed destination resort (Steamboat Springs) that dominates the real estate market. Population in the county grew by $40 \%$ during the past decade

\footnotetext{
${ }^{3} \mathrm{http}: / /$ www.farmland.org/rocky_mountain/strategic_ranchlands 1. htm
} 
Table 2. Summary of ownership and sales in case study counties.

\begin{tabular}{|c|c|c|c|}
\hline & $\begin{array}{c}\text { Routt } \\
\text { County, CO }\end{array}$ & $\begin{array}{c}\text { Sublette } \\
\text { County, WY }\end{array}$ & $\begin{array}{c}\text { Carbon } \\
\text { County, MT }\end{array}$ \\
\hline \multicolumn{4}{|l|}{ Total Acres in } \\
\hline Agriculture (2002) & 700556 & 544984 & 670832 \\
\hline \multicolumn{4}{|l|}{ Total Acres in } \\
\hline \multicolumn{4}{|l|}{ Agricultural Operations } \\
\hline$\geq 400$ Acres (2002) & 600526 & 515679 & 557542 \\
\hline \multicolumn{4}{|l|}{ Total No. of Agricultural } \\
\hline \multicolumn{4}{|l|}{ Operations $\geq 400$} \\
\hline Acres (2002) & 280 & 176 & 316 \\
\hline \multicolumn{4}{|l|}{ No. of Sales $\geq 400$} \\
\hline Acres (1990-2001) & 107 & 79 & 43 \\
\hline \multicolumn{4}{|l|}{ Acreage in Sales $\geq 400$} \\
\hline Acres (1990-2001) & 243331 & 143546 & 88874 \\
\hline \multicolumn{4}{|l|}{$\begin{array}{l}\text { Approximate Percentage of } \\
\text { Acreage in Agricultural } \\
\text { Operations } \geq 400\end{array}$} \\
\hline Acres Sold (1990-2001) & $41 \%$ & $28 \%$ & $16 \%$ \\
\hline
\end{tabular}

(from 14088 in 1990 to 19690 in 2000). The average sale price of a single-family home in the county rose from $\$ 156000$ in 1992 to $\$ 314000$ in 2000 (\$539 000 in Steamboat Springs proper).

About 700556 acres of land were classified as agricultural by the Routt County tax assessor in 2002. Of that, some 600526 acres, or $86 \%$, were part of agricultural operations greater $\geq 400$ acres in size. There were 280 such operations in the county (Table 3$)$. About half of these owners $(47 \%)$ listed mailing addresses outside the county, although the number of absentee owners may be higher given that many out-of-state owners maintain local mailing addresses.

We found 107 ranch sales totaling $\geq 400$ acres during our study period (1 January 1990 to 31 December 2001; Table 3). Some 243331 acres changed hands, making the average sale size 2274 acres. Thus, when compared with the number and acreage of such ranches in 2002, more than a third $(38 \%)$ of the operations and $41 \%$ of the land in such ranches in Routt County changed ownership during the 12-year study period.

When we classified the buyers, we found that the largest class of ranch sales in Routt County during the past decade, by far, went to "amenity buyers" (Table 3). Of the 107 ranch sales during the time period, 56 sales representing 156203 acres, or $64 \%$ of the total acreage sold, went to this group. Developers, traditional ranchers, and investors all competed for a distant second with 14, 12, and 11 sales going to these groups, respectively. Developers bought 17716 acres $(7 \%)$ of the land sold; traditional ranchers bought 17520 acres, also 7\% of the land sold; and investors bought 25802 acres (11\%) of the land sold. Most ranch sales during the 1990s involved nonlocal buyers: $71 \%$ of the sales and $83 \%$ of the land sold went to buyers with mailing addresses outside the county.

\section{Sublette County, Wyoming}

Sublette County is located in west central Wyoming, on the western flank of the Wind River Range. The county lacks
Table 3. Number of ranches sold and acreage sold by buyer type and county (1990-2001).

\begin{tabular}{|c|c|c|c|}
\hline & $\begin{array}{c}\text { Routt } \\
\text { County, CO }\end{array}$ & $\begin{array}{c}\text { Sublette } \\
\text { County, WY }\end{array}$ & $\begin{array}{c}\text { Carbon } \\
\text { County, MT }\end{array}$ \\
\hline \multicolumn{3}{|l|}{ No. (\%) of Sales to: } & 43 \\
\hline Traditional Ranchers & $12(11 \%)$ & $13(16 \%)$ & $9(21 \%)$ \\
\hline Part-time Ranchers & $3(3 \%)$ & $4(5 \%)$ & $4(9 \%)$ \\
\hline Amenity Buyers & $56(52 \%)$ & $42(53 \%)$ & $10(23 \%)$ \\
\hline Developers & $14(13 \%)$ & $10(13 \%)$ & $1(2 \%)$ \\
\hline Investors & $11(10 \%)$ & $3(4 \%)$ & $11(26 \%)$ \\
\hline Corporations & $3(3 \%)$ & $0(0 \%)$ & $1(2 \%)$ \\
\hline \multicolumn{4}{|l|}{ Conservation } \\
\hline Organizations & $2(2 \%)$ & $0(0 \%)$ & $1(2 \%)$ \\
\hline Other & $2(2 \%)$ & $4(5 \%)$ & $0(0 \%)$ \\
\hline Unclassified & $4(4 \%)$ & $3(4 \%)$ & $6(14 \%)$ \\
\hline Acreage in Sales $\geq 400$ Acres & 243331 & 143546 & 88874 \\
\hline \multicolumn{4}{|c|}{ Acreage (\% of Acreage) Sales to: } \\
\hline Traditional Ranchers & $17520(7 \%)$ & 25410 (18\%) & $17366(20 \%)$ \\
\hline Part-time Ranchers & $2072(1 \%)$ & $4072(3 \%)$ & $2717(3 \%)$ \\
\hline Amenity Buyers & $156203(64 \%)$ & $85835(60 \%)$ & $12895(15 \%)$ \\
\hline Developers & $17716(7 \%)$ & $15079(11 \%)$ & $767(1 \%)$ \\
\hline Investors & $25802(11 \%)$ & $7712(5 \%)$ & $20169(23 \%)$ \\
\hline Corporations & $14292(6 \%)$ & $0(0 \%)$ & $26399(30 \%)$ \\
\hline \multicolumn{4}{|l|}{ Conservation } \\
\hline Organizations & $1281(1 \%)$ & $0(0 \%)$ & $4212(5 \%)$ \\
\hline Other & $2809(1 \%)$ & $2497(2 \%)$ & $0(0 \%)$ \\
\hline Unclassified & $5636(2 \%)$ & $2941(2 \%)$ & $4348(5 \%)$ \\
\hline
\end{tabular}

a major resort like Steamboat, but its northern portion is a 1-hour drive from Jackson, Wyoming. Population in the county grew by $22 \%$ between 1990 and 2000 (from 4843 to 5920 ).

Sublette offers an attractive landscape of mountains, large valley-bottom areas, and extensive sagebrush rangelands. A key area is the Upper Green River Valley, which offers both productive and scenic rangelands and is home to several large cattle ranches. Settled as a pastoral economy, the county boomed with energy development in the late 1970s and experienced an economic slump in the mid-1980s when the energy economy collapsed, interest rates increased, and cattle prices declined. According to local observers, this forced the first significant wave of ranch sales to nonranchers. A few purchases by high-profile individuals were quickly emulated by other amenity seekers when outside attention was brought to this charismatic ranch landscape. Land appreciation and the dearth of ranchland for sale in neighboring Teton County (with its major resorts like Teton Village and Jackson Hole) continued to drive the Sublette County ranch market in the 1990s and early 2000s.

In the summer of 2002, Sublette encompassed 592020 privately owned acres, constituting $19 \%$ of the county. Most of the private land in Sublette, like other western counties, is designated as "agricultural land" by the tax assessor: 544984 acres or $92 \%$. We found 515679 acres (95\%) of the land in agriculture to be part of operations $\geq 400$ acres. There were 
176 such owners in the county in $2002,38 \%$ of whom listed mailing addresses outside the county.

Between 1 January 1990 and 31 December 2001, 79 ranch sales occurred, involving a total of 143546 acres. The average sale was for 1817 acres whereas the median sale size was slightly smaller (1 077 acres), and the largest single sale (14 000+ acres) was sold by a rancher to an amenity buyer in 2001. When compared with the current number of such agricultural operations (176), the sales data indicate that almost half $(45 \%)$ of the operations changed hands in the past decade. In terms of acreage, we conclude that about a quarter of the land in agriculture changed hands.

As in Routt County, the majority of the acreage sold in Sublette-85835 acres or $60 \%$-went to what we called amenity buyers, who were involved in 42 of the 79 sales (Table $3)$. Traditional ranchers were the next largest group of buyers, accounting for 25410 acres $(18 \%)$ of the land sold, in a total of 13 transactions. Ten sales went to developers, involving 15079 acres $(11 \%)$ of the land sold, while part-time ranchers bought 4072 acres $(3 \%)$ in 4 sales during the decade. The majority of Sublette County ranch buyers were nonlocals: $66 \%$ of the sales and $70 \%$ of the land sold went to buyers with addresses outside the county.

\section{Carbon County, Montana}

Located in south central Montana, 60 miles southwest of Billings, Carbon County covers a diversity of terrains. The alpine Beartooth Plateau dominates the southwestern horizon in the county, while the county's northern reaches are in open plains along the Yellowstone River. Rock Creek, the primary drainage, runs through Red Lodge, the county seat and a popular tourist destination. Like other south central Montana counties, and in contrast to mountain counties in Wyoming and Colorado, Carbon exhibits a slight preponderance of private land $(56 \%$ of the county's area).

Carbon is the least developed of our study areas and exhibits the largest proportion among the study counties of land designated agricultural by the tax assessor $(97 \%$ or 677445 of the county's 695383 private acres). We found 316 operations incorporating $\geq 400$ deeded acres, accounting for $82 \%$ (558 157 acres) of the land in agriculture. Thirty-nine percent of the ranch owners in 2002 listed addresses outside the county.

Although Carbon had the largest number of ranches among our 3 study counties, it showed the fewest sales between 1990 and 2001: only $43(14 \%)$ of the ranches in the county changed hands. We verified this sales rate by interviewing several real estate professionals familiar with the county. The 43 ranch sales involved 88874 acres $(15 \%)$ of the agricultural land in the county, with a median sale size of about 767 acres.

About half of the sales went to a combination of investors $(26 \%)$ and amenity buyers (23\%) (Table 3$)$. Twenty-one percent went to traditional ranchers. The largest share of the land sold (26 399 acres or $30 \%$ ), however, went to a single energy corporation in one big sale in 1992. Excluding that one sale, $31 \%$ of the acreage went to investors, $29 \%$ to traditional ranchers, and $20 \%$ to amenity buyers. Only one sale that we are aware of went to a developer. Fifty-six percent of the sales and $78 \%$ of the land sold went to buyers with addresses outside the county.

\section{DISCUSSION}

We cannot determine whether the ranchland turnover we found in this study is unusually high in a historical sense, as some observers suggest (Holechek 2001). Our results fit within the context of widely discussed changes in ranch ownership and accord with the limited extant research on ranchland ownership. Huntsinger and Fortmann (1990) found in the early 1990s that roughly one-third of the privately owned oak woodlands in California had changed hands in 7 years. The survey of public lands ranchers by Gentner and Tanaka (2002) found an almost even split between professionals and hobbyists. Several papers pointing to increased diversity of ranchland ownership were recently presented in a symposium on "the changing faces of rangeland users" at the 2004 meeting of the Society for Range Management (e.g., Torell et al. 2004; Huntsinger and Sulak 2004).

Our 3 study counties represent the diversity among ranch landscapes in the Rocky Mountain West with correspondingly diverse patterns of ownership change during the past decade. Routt County, Colorado, the most developed county and home to a major resort, reflects what is happening in other resort areas of the Rockies. The relatively low percentage of land in agricultural operations suggests a more fragmented landscape because of the pressure for subdivision, especially for second homes. Routt County also saw the highest number of sales and largest acreage sold among our study counties (about a quarter of a million acres, nearly 3 times the acreage sold in Carbon County). The largest share of sales and acres sold went to outof-state amenity buyers and investors-many of whom were adding to existing holdings in the county.

Sublette County is less developed, but it is close to resorts in Jackson Hole and has attracted increased interest in ranch property for amenity uses. Sublette saw the highest percentage of ranches (nearly half) change hands during our study period. Although it is more than twice as large as either of our other study counties, Sublette has fewer private acres, and thus a much higher percentage of public land. Most ranches share a boundary with public land, a much sought-after quality among amenity buyers, along with trout streams, mountain views, and privacy. Sublette also contained a greater proportion of large ranch operations than the other counties, suggesting a more intact ranching landscape that is especially attractive to wealthier amenity buyers. Sublette reflected Routt County in the proportion of sales to amenity buyers and traditional ranchers; more than half of the ranch sales and total acreage sold in both counties went to amenity buyers. Sublette saw slightly more sales to developers, including an unusual type of ranch development: the "fishing ranch," in which cattle are removed, and lots adjoining a trout stream are sold, but buildings and fences are discouraged.

The least developed of our study areas, Carbon County, with the largest number of ranches and greatest proportion of its private land in agricultural use, saw the least sales activity: barely $15 \%$ of its ranches changed hands. A smaller proportion of these sales were to amenity buyers, indicating that traditional ranchers are still active in Carbon County's agricultural land market. Is this perhaps due to less outside demand? We asked several people familiar with the Carbon County ranch real estate market to help us understand the situation. According to one 
realtor, "Lots of people are requesting large ranches around Red Lodge, but there's no availability—people aren't selling." This realtor explained that the "old timers" have held out pretty well and that there were probably only about 3 to 5 large ranch sales per year in the county (an estimate that matches our findings). A local NRIS employee agreed that, although land ownership in western and central Montana has been changing rapidly, these trends were not as apparent in Carbon County.

The rates of ranch sales found in Routt and Sublette Counties during the study period suggest that the majority of ranch properties will have changed hands in $<2$ decades in those areas. Many of the large ranches in the Rockies are already in nontraditional hands, and it is likely that another decade of sales will mark the end of all but a very few traditional ranches in the most amenity-rich areas. But perhaps the most surprising result of this study is the relatively low rate of turnover in Carbon County, which nevertheless offers many similar ranchland amenities.

These results can be interpreted in light of conceptualizations of the human dimensions of range and ranchlands that build on the resilience/stability concepts offered by Westoby et al. (1989). Peterson and Coppock (2001) proposed such a socioeconomic state-and-transition model, and it is implicit in Holechek's (2001) notion of the western range at a "crossroads." Huntsinger and Hopkinson (1996) also suggested that a tipping-point model might be appropriate for assessing ranchland conversion, in which a changing ownership regime results in a cascading reconfiguration of land use and land cover. Our hypothesis is that the amenity demand for ranches is a major, regional controlling variable in a state-and-transition model of ranchland ownership. Some western ranch landscapes have already transitioned to a new regime dominated by amenity ownership (e.g., Routt County, in which the transition was occasioned by the growth of a destination resort), whereas others with the requisite conditions are undergoing a cascade of sales (Sublette County). Finally, some areas (Carbon County) remain short of this tipping point, awaiting a particular sale that results in a cascade of purchases (the demand side) or an economic swing or flurry of rancher retirements that makes more properties available (supply side).

What might this mean for the conservation of ranching and rangeland values? Our findings suggest that new forms of ranching, such as ranch families managing land that is owned by absentee amenity seekers or conservation owners, are already in place in the Rockies. If we are to maintain ranchlands as valuable economic, cultural, and ecological landscapes (as called for by Huntsinger and Hopkinson 1996), we should study these new arrangements, gain a better understanding of their pros and cons, and assess their role in sustaining the rangeland landscape.

Change in ranchland ownership has implications for several aspects of range ecology and management. We found in interviews associated with the data collection for this study that some traditional ranchers and range professionals believe that sales to owners lacking ranching experience will lead to land degradation, whereas some conservationists believe that the ownership transition could yield more conservation-oriented land uses. We heard anecdotes about new owners revamping range and livestock management practices, about changes in public land grazing allotments, about changes in local politics and economics, and about concerns over noxious weed control. These implications deserve careful analysis in future research.

Despite widespread concern over the transition in ranchland ownership, it may be that an emerging new rangeland community-comprising traditional ranchers, amenity ranchers, and ranch managers-can maintain many of the desirable qualities of western rangeland landscapes.

\section{ACKNOWLEDGMENTS}

The authors gratefully acknowledge the assistance of Julia Haggerty and Tom Dickinson at the Center of the American West and the valuable suggestions of the technical editor and 2 anonymous referees.

\section{LITERATURE CITED}

[AFT] American Farmland Trust. 2002. Strategic ranchland in the Rocky Mountain West: Mapping the threats to prime ranchland in seven western states. Washington, DC. Available at http://www.farmland.org/rocky_mountain/ strategic_ranchlands1.htm. Accessed 24 June 2004.

Anderson, D. P., J. W. Richardson, R. D. Knutson, J. C. Namken, T. R. Harris, W. 0. Champney, T. R. MacDiarmid, and A. B. Marshall. 1993. Alternative grazing fee formula impacts on representative public land ranches. Journal of Range Management 46:548-554.

Baron, J. S. [ED.]. 2002. Rocky Mountain futures: An ecological perspective. Washington, DC: Island Press. 325 p.

Bartlett, E. T., R. G. Taylor, J. R. McKean, and J. G. Hof. 1989. Motivation of Colorado ranchers with federal grazing allotments. Journal of Range Management 42:454-457.

Coppock, D. L., AND A. H. BiRKENFELD. 1999. Use of livestock and range management practices in Utah. Journal of Range Management 52:7-18.

Fowler, J. M., AND J. R. Gray. 1988. Rangeland economics in the arid West. In: B. A. Buchanan [ed.]. Rangelands (Contributions of the Committee on Desert and Arid Zones Research of the Southwestern and Rocky Mountain Division of the American Association for the Advancement of Science). 1st ed. Albuquerque, NM: University of New Mexico Press. p. 67-89.

Gentner, B. J., and J. A. Tanaka. 2002. Classifying federal public land grazing permittees. Journal of Range Management 55:2-11.

HolecheK, J. L. 2001. Western ranching at the crossroads. Rangelands 23(1): $17-21$.

Huntsinger, L., L. ButTolPh, AND P. Hopkinson. 1997. Ownership and management changes on California's hardwood rangelands, 1985-1992. Journal of Range Management 50:423-430.

Huntsinger, L., and L. P. Fortmann. 1990. California's privately owned oak woodlands: owners, use, and management. Journal of Range Management 43:147-152.

HuntsingeR, L., AND P. HopkINSON. 1996. Sustaining rangeland landscapes: a social and ecological process. Journal of Range Management 49:167-173.

HuntsingeR, L., AND A. Sulak. 2004. Western ranching: Loving it or leaving it. Proceedings: The changing faces of rangeland users: implications for management and rangeland sustainability, Annual meeting of the Society for Range Management; 25-30 January 2004; Salt Lake City, UT.

JoRdAN, T. G. 1993. North American cattle ranching frontiers: origins, diffusion, and differentiation. Albuquerque, NM: University of New Mexico Press. $439 \mathrm{p}$.

Liffmann, R. H., L. Huntsinger, and L. C. Forero. 2000. To ranch or not to ranch: home on the urban range? Journal of Range Management 53:362-370.

MitcheLL, J. E. 2000. Rangeland resource trends in the United States. Fort Collins, Colo.: USDA, Forest Service, Rocky Mountain Research Station. General Technical Report RMRS-GTR-68. Available from: NTIS, Springfield, VA. 
Peterson, R., and L. Coppock. 2001. Economics and demographics constrain investment in Utah private grazing lands. Journal of Range Management $54: 106-114$

Rowan, R. C. 1994. Are small-acreage livestock producers real ranchers? Rangelands 16(4):161-166.

Rowan, R. C., and J. P. Workman. 1992. Factors affecting Utah ranch prices. Journal of Range Management 45:263-266.

Sengupta, S., and D. E. Osgood. 2003. The value of remoteness: a hedonic estimation of ranchette prices. Ecological Economics 44:91-103.

Smith, A. H., AND W. E. MaRTin. 1972. Socioeconomic behavior of cattle ranchers with implications for rural community development in the West. American Journal of Agricultural Economics 54:217-225.

StaRRS, P. F. 1998. Let the cowboy ride: cattle ranching in the American West. Baltimore, MD: Johns Hopkins University Press. $384 \mathrm{p}$

ToreLL, L. A., AND M. E. KincAid. 1996. Public land policy and the market value of New Mexico ranches, 1979-1994. Journal of Range Management 49: 270-276.
Torell, L. A., N. R. Rimbey, O. A. Ramirez, and D. W. McCollum. 2003. Recent trends and factors influencing the market value of New Mexico ranches. New Mexico Section Newsletter, Society for Range Management. Available at http:// usda-ars.nmsu.edu/JER/SRMSummr2003.htm. Accessed 24 June 2004.

Torell, L. A., N. R. Rimbey, O. A. Ramirez, and D. W. McCollum. 2004. New faces and the changing market value of western ranches. Proceedings: The changing faces of rangeland users: implications for management and rangeland sustainability, Annual meeting of the Society for Range Management; 25-30 January 2004; Salt Lake City, UT.

[USDA] United States Department of Agriculture, Economic Research Service. 2000. ERS farm typology for a diverse agricultural sector. Bulletin No. 759. Available at http://www.ers.usda.gov/publications/aib759/aib759.pdf. Accessed 24 June 2004.

Westoby, M., B. Walker, and I. Noy-MelR. 1989. Opportunistic management for rangelands not at equilibrium. Journal of Range Management 42: 266-274. 